\title{
TREATMENT OF DEATH IN NORMAN MAILER'S $A N$ AMERICAN DREAM
}

\author{
JUAN JOSÉ TORRES NÚÑEZ. \\ Universidad de Almería
}

\begin{abstract}
In the following article I show that in Norman Mailer's novel An American Dream cancer is everywhere. Cancer is used by Mailer to express universal madness. There is not one single instance of love in the whole book. Love is as real as murder and it has more power. Love becomes death. But there is only one instance in the novel where love seems to appear and that is in the honest attempt of the writer to convey the significance of that death. Norman Mailer loves his country. And like Joseph Heller, he is saying that Something Happened to America.
\end{abstract}

In Norman Mailer's novel An American Dream, the American dream of success becomes a nightmare. The novel tells us to what extent class, money and power can control our ideas. The last short chapter of Norman Mailer's novel The Armies of the Night is called: 11: THE METAPHOR DELIVERED. Here we read that America "is heavy with child" and she will probably give birth to a babe that can become either "the most fearsome totalitarianism the world has ever known", or, a "tormented lovely girl... a babe of the new world brave and tender..." (p. 320).

In An American Dream, we wonder whether this babe has been delivered stillborn because everything we see in the story is dead. Cancer is everywhere in An American Dream. However, we do not see anybody in the sickbed dying of this disease, only the man in the Epilogue and he had already died. Death takes the form of murder; therefore cancer is a metaphor for the madness of society. In this light, the novel could be read as an extension of Joseph Heller's book Catch-22. The insanity of the society that Heller conveys in his work, has become evident in An American Dream. Mailer (1964: 249-250) is not talking literally about cancer; he is not talking about a society that is going mad as in Catch-22; he is talking about a society that is already mad. Rojack says:

In some, madness must come in with breath, mill through the blood and be breathed out again. In some it goes up to the mind. Some take the madness and stop it with discipline. Madness is locked beneath. It goes into tissues, is swallowed by the cells. The cells go mad. Cancer is their flag. Cancer is the growth of madness denied. In that corpse 
I saw, madness went down to the blood... some of the real madness went into me. The stink of the dead man went along the dry lands of Oklahoma and northen Texas, through the desert bake of New Mexico, Arizona, on into the valleys of the moon.

This paragraph shows that Mailer is using cancer as a metaphor. Cancer can never be "the growth of madness denied". It is precisely madness with which he is concerned, not cancer. And it is not suprising that this paragraph appears at the end of the novel, in the Epilogue. It seems to be a type of moral allegory for what Mailer is trying to convey.

Another example of cancer used metaphorically can be seen when Rojack first meets Tony:

"Too bad about your wife."

"Dreadful," I said.

It did not put him off. "I used to know her," he said.

"For fact?"

...

"Yes," said Tony, "your wife, Mr. Rojack, was a real swinger." "You know," I said to Tony, "it's a pity about your uncle's disease."

"He takes it well," said Tony.

On that echo, I left with [Cherry]. (An American Dream, p. 113).

There is an abrupt shift in the conversation. Rojack is more interested in knowing about his wife's lovers, as he showed minutes before he murdered her. He repeatedly asked her, "How many lovers do you have?" Mailer seems to be conveying the idea of a plague of which Deborah, Rojack's wife, is involved. Cancer is portrayed as a social disease and the "swinging" behaviour of Deborah is the reflection of that malady. Deborah, like Daisy in The Great Gatsby, is the American "bitch".

Edward Bond (1977: 241) also uses cancer as a metaphor. He compares our society to living in a jungle and believes that this society is plagued with cancer. The characters of his play The Pope's Weding make the following comments:

Ron. Owd Tanner Lob's gooin', then.

Lorry. Cancer all over.

Scopey. I'erd it got' is lungs.

Joe. Up' is pipe.

Ron. Runnin' all over.

Bill. On the brain.

Lorry. 'E won't be 'arvestin' this year.

Ron. Ready?

Bill. No.

Lorry. Fair owd day, ent it.

Byo. It got 'im in the groin.

Ron. Yoo got it in the groin.

Byo. I got somethin'. 
Edwar Bond thus uses cancer and violence as a metaphor to express universal sickness. He thinks that violence shapes our society and it would be immoral not to write about it.

An American Dream starts with the crimes committed in Italy during World War II and ends with the unbearable smell of the dead man undergoing autopsy. In between these two events we have one murder after another. Only one man dies of cancer in the novel but we find this out in the Epilogue. The smell of his death spreading throughout the barren empty land at the time of the year "near the beginning of April", echoes the opening lines of T.S. Eliot's Waste Land.

April is the cruelest month breeding

Lilacs out of the dead land, mixing

Memory and desire, stirring

Dull roots with spring rain. (ll. 1-4)

The above example demonstrates how cancer is used by Mailer as a fictional technique to express universal madness. The characters we find in the novel are degenerates, murderers or shallow superficial people. There is not one single instance of love in the whole book. Love is reduced to the level of incest, murder, coin, and "coin [is] power" (p. 228). In the novel, love is as real as murder and it has more power. To go to bed with someone is to kill. In the world presented in an An American Dream there is no innocence. When Rojack goes to bed with Deborah, Kelly (his father) had been there before. And when Rojack goes to bed with Ruta and Cherry, Kelly had been there before too. Everything is carnal and animalistic. The novel is full of animal imagery. Characters are described as resembling cats, dogs, horses, snakes. Rojack for example, wants sex not for pleasure or love but to reduce the tension caused by the murder he has committed. People want to make love -or rather have sex- immediately after a death. In Rojack's words:

I could hear what he [Kelly] offered now: bring Ruta forth, three of us to pitch and tear and squat and lick, swill and grovel on that Lucchese bed, fuck until our eyes were out, bury the ghost of Deborah by gorging on her corpse, for this had been the bed, yes, this Lucchese had been the bed where he went out with Deborah to the tar pits of the moon. (p. 237)

Society is depicted as a jungle where all the animals meet to mate and Man becomes a part of that jungle. There is no love even in the relationship between Cherry and Rojack. As Rojack says:

We did not meet as lovers, more kike animals in a quiet mood, come across a track of the jungle to join in a clearing, we were equals. (p. 120)

Similarly: 
Nothing was loving in her; no love in me... I had some distant awareness that my breath could hardly be good and her lungs breathed back an air of ashes and the tomb... (p. 121)

The act of love thus becomes an act of death in life:

When I [Rojack] was in bed with a woman, I rarely felt as if I were making life, but rather as if I were a pirate sharpening up a raid on life. (p. 115)

This death of love appears in Hemingway's novel The Sun Also Rises, where everybody is wounded -psychologically as well as physically- as a result of the First World War. Thus, being wounded becomes a symbol for the universal wound. In An American Dream, written after the Second World War, the wound has not healed yet, it has become cancerous and this is another symbol for the universal disease. Man is a product of the environment in which he lives; as a result, war does not produce heroes but criminals. An example of this is Rojack, a graduate from Harvard, "an athlete" and an "excessively bright student", who learns how to kill for the first time during the War. That particular moment in the hills of Italy where the eyes of the four Germans were staring at him has remained with him throughout his life. He becomes imprisoned by them even when he murders his wife. However, this cannot justify Rojack's murder but, on the contrary, it serves to point out the type of Man that society is producing after the War. In Rojack's words:

I had learned to speak in a world which believed in the New York Times... I had lost my faith in all that by now: now I swam in the well of Deborah's intuitions; they were nearer to my memory of the four Germans than anything encountered before or since. (p. 400)

Rojack is a product of post-war society, a society where even the sky above is full of "grangrene". We read in the Epilogue:

Nobody knew that the deserts of the West, the arid empty wild blind deserts, were producing again a new breed of man... I was part of the new breed. (p. 251)

In this type of society, incest becomes an apprenticeship for political success. When Cherry talks about her brother she says: "Brother was sticking it into sister every night..." Rojack asks her, "What does he do now?", and she answers: "Sheriff. Last I heard he was running for State Legislature... I guess all that incest taught him how to move politically". (p. 159)

The pestilence of this "grangrene" also reaches the government. We see a mob of people like Ganucci and Kelly who have become millionaires by dealing in narcotics. Probably they are in control of the C.I.A. and even of the administration of justice. After all, Rojack is set free even when the police know that he has committed the murder. But Kelly wants it that way. We know Kelly has connections with the C.I.A., so he is afraid of Rojack's being investigated. As Ruta says to Rojack: 
The had to let you go. Since nobody can know if you know a little or a lot, a real investigation would be ending der Teufel knows where. (p. 212)

In any direction that we look in An American Dream, death is always omnipresent. It is part of the landscape; it is part of the disease of the people who are dead in life. Ashes are everywhere even in the color of some people's hair. Love becomes death; death is in the air we breath, in our social institutions, everywhere. But there is only one instance in the novel where love seems to appear and that is in the honest attempt of the writer to convey the significance of that death. The writer here is like a doctor who diagnoses his patient's disease not because he wants to kill her but because he wants her to be cured. Norman Mailer loves his country. And like Joseph Heller, he is saying that Something Happened to America.

In An American Dream, Rojack is thus the embodiment of the American dream and its subsequent degeneration into a series of nightmares. Norman Mailer depicts the postwar spiritual vacuum that Eliot in The Waste Land and Fitzgerald in The Great Gatsby describe so well. What they seem to conveny is the desolation and despair of Western Civilization.

An American Dream demands an account of those responsable for this state of affairs. The answer, however, is one of despair: there is no answer. Rojack is not punished, even though he is demonic and cruel. Unfortunately -like in Milton's Paradise Lost- Satan is everywhere. And the society portrayed in An American Dream is satanic, arid, empty and futile. It is the "valley of ashes" of our chaotic human condition.

\section{REFERENCES}

MaILER, N. 1964. An American Dream. Dell.

MaILER, N. 1968. The Armies of the Night. Signet.

Bond, E. 1977. Plays: One. Eyre Methuen.

Bond, E. 1978. Plays: Two. Eyre Methuen.

Hemingway, E. 1926. The Sun Also Rises. Scribners.

FitzGerald, F.S. 1925. The Great Gatsby. Scribners.

Heller, J. 1955. Catch-22. Dell.

Heller, J. 1966. Something Happened. Ballantine Books. 